\title{
HONESTY AND INTEGRITY IN THE KOE, IIUM
}

\author{
NASSERELDEen AHMED KabBaSHI \\ Department of Biotechnology Engineering, \\ Faculty of Engineering, International Islamic University Malaysia, \\ P.O. Box 10, 50728 Kuala Lumpur, Malaysia.
}

nasreldin@iium.edu.my

\begin{abstract}
The universities and education face great challenges, most of them indirectly or directly related to science. Academic honesty and integrity are fundamental values in a community of scholars. The student shares with the faculty the responsibility for maintaining the integrity of scholarship, grades, and professional standards, therefore students at university develop habits that help them to survive. It is necessary for scholars to think and work as a student, and resume the methods developed during undergraduate days. Scholars at the Kulliyyah of Engineering (KOE) International islamic University (IIUM), must satisfactory engage in learning with their students and in various forms of community service and industry liaison, in addition to attend several meetings per semesters. Those pressures can attempt people to take short-cut that do not meet KOE community standards for honesty and integrity. At the KOE incidents of student cheating are very low but the cases start to increase. This paper tries to highlight the reason behind why honesty and integrity among scholars break down and why cases of cheating among students increased as well.
\end{abstract}

ABSTRAK: Pihak universiti dan pendidik menghadapi cabaran yang hebat, kebanyakannya secara langsung atau secara tidak langsung berkaitan dengan sains. Ketulusan akademik dan kewibawaan merupakan nilai-nilai asas dalam komuniti cendekiawan. Para sizwazah berkongsi dengan pihak fakulti tanggungjawab dalam memelihara kewibawaan biayaan, gred, dan standard profesional. Dengan ini, siswazah universiti dapat membentuk amalan yang membantu mereka cemerlang. Ia adalah penting bagi para cendekiawan untuk memikir dan bekerja sama dengan pelajar, dan meneruskan kaedah yang dikembangkan semasa zaman prasiswazah. Para intelektual di KOE, IIUM harus terlibat dalam pengajaran dengan pelajar-pelajar mereka dalam pelbagai bentuk khidmat masyarakat serta kerjasama dengan industri, selain daripada menghadiri mesyuarat setiap semester. Tekanan-tekanan sebegini boleh mendorong agar tidak mengambil jalan mudah yang tidak memenuhi standard komuniti di KOE dari segi keikhlasan dan kewibawaan. Di KOE, insiden pelajar menipu adalah rendah tetapi hal ini makin meningkat. Kertas ini cuba mengetengahkan sebab kenapa ketulusan dan keutuhan di kalangan siswazah makin runtuh dan kenapa kes-kes penipuan di kalangan pelajar semakin meningkat.

KEYWORDS: integrity; honesty; IIUM; KOE; Allah (SWT)

\section{INTRODUCTION}

The International Islamic University Malaysia (IIUM) Kulliyyah of Engineering (KOE), being the newest in Malaysia, admitted its first batch of students in June 1994. It has many features common in other Malaysian universities: content of the medical curriculum, duration of studies, examinations, and practical training. It in addition has unique characteristics of its own being Islamic and international. It has an integrated 
curriculum in which moral and ethical values are taught with the academic and practical aspects. IIUM does not accept the distinction between ethics as a set of regulations agreed on by consensus in a particular profession and morality as basic inner beliefs. Ethics must reflect basic morality otherwise, like any other human rules they can be circumvented by using one loop-hole or another. Ethics cannot be learned in a course but can only be internalized so that they become part of the student's personality. The supreme objective is to produce a physician who will act ethically without consciously thinking about rules and regulations. Ethical behavior will have become part of behavior as is eating and drinking. The aim is to make sure that ethical behavior is not prompted by fear of punishment or promise for any reward. The only motivation should be from the inner conviction of the physician. Being an Islamic university, the teaching of ethics is based on the Islamic value system. These are the universal human values found in several other faiths and philosophies of life. Islam as a religion and way of life has the unique distinction of claiming universality in its basic teachings, practice, cultural, and intellectual values. It is therefore very easy for non-Muslim students to follow and understand the ethical input into the curriculum.

\section{THE INTEGRATION OF ISLAMIZATION CURRICULUM}

Islamic epistemology is based a central principle, Allah (SWT) is the source of all knowledge. Three main sources arise regarding to knowledge. God's teaching to Adam (pbuh), revelation as of Qur'an and Sunnah principles, and fitrah of human beings. Knowledge ('ilm) occupies a dominant position in the Islamic world-view. According to Franz Rosenthal, 1970, 'in Islam, the concept of knowledge enjoyed an importance unparalleled in other civilizations'. It dominated over all aspects of Muslim intellectual, spiritual and social life. Twentieth century of science began by asking what is the material, why do materials have different properties, what are the ethics of using those materials as weapons in the wars, as genetic modified organisms etc. The holy Qur'an and the Sunnah of the Prophet (pbuh) should be the primary references in understanding the nature of the learner and knowledge. The major step for the Islamization of the Curriculum is to ensure that the sources of educational purposes are drawn from the Islamic worldview, whether they are about the background of the learner, the character of the knowledge or the subject specialization, or current life itself.

\subsection{Tawhid}

All the Islamic courses at the Kulliyyah of Engineering IIUM mainly concentrate on Unity (Tawhid) Allah (SWT) said in the holy Qur'an "Verify those who say: 'Our Lord is Allah, and remain firm on that path on them shall be no fear, nor shall they grieve" (Qur'an, 46:13)[1]. Therefor all UNGS courses which explained in the coming section focused on Tawhid.

\subsection{Vision}

The formulation of a clear philosophy of education based on the Islamic worldview is a must in any educational sector. It is crucial to act as the educational guide for the state, school leaders, teachers, parents and students. Clear goals and objectives of education must be spelled out as of IIUM where followed the University's vision, IIUM Endeavour's:

- To undertake the special and greatly needed task of reforming the contemporary Muslim mentality and integrating Islamic Revealed Knowledge and Human Sciences in a positive manner. 
- To produce better quality intellectuals, professionals and scholars by integrating the qualities of faith ( iman ), knowledge ( 'ilm ), and good character ( akhlaq ) to serve as agents of comprehensive and balanced progress as well as sustainable development in Malaysia and in the Muslim world.

- To foster the Islamization of the ethics of Muslim academic and administrative staff of IIUM, and certain aspects of human knowledge - particularly in the social sciences and humanities - with the view to making them more useful and more relevant to the Muslim Ummah.

- To nurture the quality of holistic excellence which is imbued with Islamic moralspiritual values, in the process of learning, teaching, research, consultancy, publication, administration and student life.

- To exemplify an international community of dedicated intellectuals, scholars, professionals, officers and workers who are motivated by the Islamic world-view and code of ethics as an integral part of their work culture.

- To enhance intercultural understanding and foster civilization dialogues in Malaysia as well as across communities and nations.

- To develop an environment this instils commitment for life-long learning and a deep sense of social responsibility among staff and students.

The summary of the Mission should read as follows:

- Integration;

- Islamization;

- Internationalization; and

- Comprehensive Excellence

\subsection{Faith and Science}

The faith and science at the Kulliyyah of Engineering taught the students all the above courses aiming to reach to the following principles which are:

$\checkmark$ Truthfulness

$\checkmark$ Trust

$\checkmark$ Sincerity

$\checkmark$ Brotherhood

$\checkmark$ Science and Knowledge

$\checkmark$ Justice

And after students graduated from the Kulliyyah, the University level and Kulliyyah level monitored those principles with their graduates, and based on the reports about alumni, University level and Kulliyyah are optimistic and proud of their graduates and of their doings, which considered as a unique brand of IIUM.

\section{INTEGRITY AND HONESTY}

A book [2] was published to emphasize the importance of professional ethics and to provide a clear understanding of the terms and concepts of engineering ethics. Several other books followed [3-4], with the most recent ones [5-7] written as textbooks for some proposed ethics courses. Students at KOE develop habits that help them to survive. This is most striking to those of us who undertook higher degrees after being in the workforce for a period; it is necessary to think and work as a student, and resume the methods developed during undergraduate days. The habits are mostly centered around maximizing marks, the 
student's single most important objective, and if a course is well crafted this will also optimizing learning.

Likewise, academic staff members strive to publish their cutting-edge research in leading scholarly journals, since that increasing their seniority, salary and occupancy. They must also satisfactorily engage in learning with their students, and in various forms of community service and industry liaison.

\section{INTEGRITY AND HONESTY FINDINGS}

Based on interviews done with with head of department of Electrical and Computer Engineering (ECE), Biotechnology Engineering (BTE) and Dean Kulliyyah of Engineering, and questionnaire with Admission and Records, KOE division on different occasions the out puts were as follows. Each staff at the KOE suffered from huge number of meetings per month, normal staff at least must attend 2 meetings per week, the Dean KOE and his two deputies at least they have 3-4 meeting per week, head of department for the 6 programs may have between 3-5 meetings per week and this one varies between department and another based on the experience of the person who headed the department who delegate his tasks to a group and they just summarize him the findings, where as a new head needs time to fully comprehend the system and then (s)he must be involved in many meetings. Table 1 shows a typical regiularly scheduled meetings for office bearers and ordinary academic staff. It should be noted that Table 1 does not include the emergency meetings, unplanned meetings etc. which puts many academic staff under jobrelated tensions and stress and may affect the staff's honesty and integrity.

Table 1: KOE management staff meetings.

\begin{tabular}{|c|c|c|c|}
\hline$\#$ & Name & Department & Number of meetings/week \\
\hline 1 & Staff member & All & 2 \\
\hline 2 & Dean KOE & KOE & $3-5$ \\
\hline 3 & HOD & Mechatronics & $4-5$ \\
\hline 4 & HOD & Biotechnology & $3-5$ \\
\hline 5 & HOD & Mechanical & $3-5$ \\
\hline 6 & HOD & $\begin{array}{c}\text { Electrical and } \\
\text { Computer }\end{array}$ & $2-3$ \\
\hline 7 & HOD & Science & $2-3$ \\
\hline 8 & HOD & $\begin{array}{c}\text { Manufacturing and } \\
\text { Materials }\end{array}$ & $2-3$ \\
\hline 9 & Director & $\begin{array}{c}\text { Advanced Engineering } \\
\text { and Innovation Centre }\end{array}$ & \\
\hline
\end{tabular}

$\mathrm{HOD}=$ head of department

These pressures can attempt people to take short-cuts that do not meet community standards for honesty and integrity. Even institutions can cheat, for example under the inspection of external auditors. It is supposed that, in an earlier era, entire libraries and computer labs appeared overnight and then misplaced after the audit visit. 
At KOE-IIUM Gombak campus incidents of cheating are not yet to a threaten level, still the students respect the high reputation of the Kulliyyah and the university vision and mission, students know that any cheating reduces the value of their degree, cases as paper cheating, some papers in toilets and inside their phones has been caught by the invigilator, this why the rules for students during exams to leave their belongings outside the exam hall, and strict checks for student's matric names, and check the toilets is very important. In education, cheating and not punishing cheating is a failure to uphold community standards. When lecturers and academic managers do not properly deal with serious incidents, they are themselves engaging corrupt conduct as seen in Table 2.

Table 2: Cheating cases at KOE, semester III, 2009-2010.

\begin{tabular}{|c|c|c|c|c|}
\hline \multirow{2}{*}{ NO. } & \multicolumn{2}{|c|}{ GENDER } & \multicolumn{2}{|c|}{ NATIONALITY } \\
\hline & Male & Female & Malaysian & International \\
\hline 1. & 1 & - & - & 1 \\
\hline 2. & 1 & - & 1 & - \\
\hline 3. & 1 & - & 1 & - \\
\hline 4. & 1 & - & 1 & - \\
\hline 5. & - & 1 & 1 & - \\
\hline 6. & 1 & - & 1 & - \\
\hline 7. & 1 & - & - & 1 \\
\hline 8. & 1 & - & - & 1 \\
\hline 9. & 1 & - & 1 & - \\
\hline Total & 8 & 1 & 6 & 3 \\
\hline
\end{tabular}

Source: Admission and Records, KOE

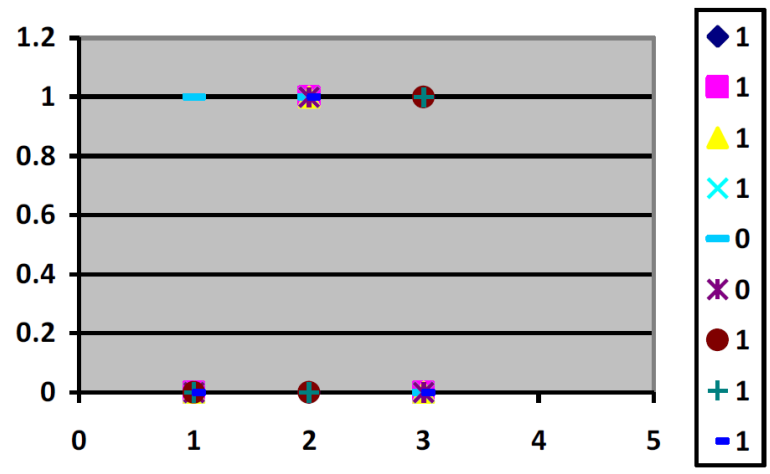

Fig. 1: Cheating cases 2009-2010. 
Honesty and integrity are among the most important values that students, academics and institutions can hold dear. These values are impaired when conflict of interest are not adequately managed, as in unfairly gaining higher marks.

At IIUM an ethics statement sets a high tone for the conduct of all staff and students. Potential conflicts of interest, which may come up in the normal course events, must be actively avoided, disclosed, and managed. When anyone is considering whether a university is good or not, inquire about honesty and integrity.

Table 3: Cheating cases at KOE, semester 1, 2010-2011.

\begin{tabular}{|c|c|c|c|c|}
\hline \multirow{2}{*}{ NO. } & \multicolumn{2}{|c|}{ GENDER } & \multicolumn{2}{c|}{ NATIONALITY } \\
\cline { 2 - 5 } & Male & Female & Malaysian & International \\
\hline 1. & 1 & - & - & 1 \\
\hline 2. & 1 & - & 1 & - \\
\hline 3. & 1 & - & 1 & - \\
\hline 4. & 1 & - & - & 2 \\
\hline Total & 4 & - & 2 & 1 \\
\hline
\end{tabular}

Source: Admission and record KOE
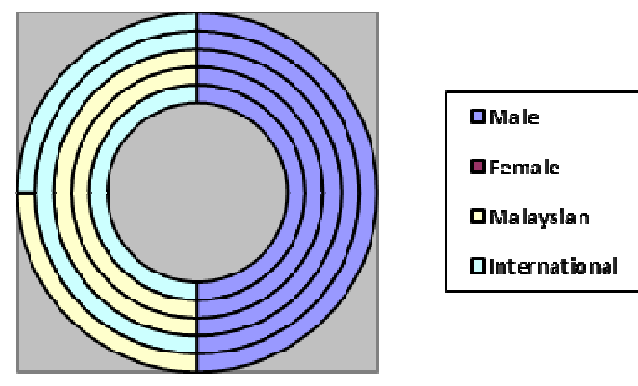

Fig. 2: Cheating cases, 2010-2011.

\section{FUTURE, CHALLENGES AND OPPORTUNITIES}

Based on all the values and ethics at KOE instilled in students by IIUM authority, perhaps none is as essential as academic integrity. Unfortunately, students are not inevitably honest. In fact, a majority of students carry questionable ethical habits into college with them. The problem of dishonesty does not trouble campus classrooms alone, but reaches far into individual persons and even it becomes culture which spread from certain groups into another specially if we know that there are ninety nine different nations and cultures inside IIUM campus.

To have a bright future for the coming generation must learn them that oneday will then become responsible themselves. It is therefore a hope that as everyone establishes a 
IIUM Engineering Journal, Vol. 12, No. 5, 2011: Special Issue on Science and Ethics in Engineering Kabbashi

promise based on trust with his students within his classroom, the model of integrity and personal integration of faith, honest, care and learning will impact their lives and encourage them to do likewise as bright future.

\section{ACKNOWLEDGMENT}

The author acknowledges all the kind help in getting the required data from admission and record division KOE and in specific brother Ahmad Hidayat and to IIUM as well.

\section{REFERENCES}

[1] Holy Qur'an, 46:13.

[2] Mantell, M.I., Ethics and Professionalism in Engineering, The Macmillan Company, New York, 1964.

[3] Florman, S.C., The Civilized Engineer, St. Martin's Press, New York, 1987.

[4] Johnson, D.G., Ethical Issues in Engineering, Prentice-Hall, Englewood Cliffs, N.J. 1991.

[5] Davis, M., Thinking Like an Engineer: Studies in the Ethics of a Profession, Oxford University Press, New York, 1998.

[6] Whitbeck, C., Ethics in Engineering Practice and Research, Cambridge University Press, 1998.

[7] Schinzinger, R. and Martin, M., Introduction to Engineering Ethics, McGraw-Hill Inc, 2000. 